\title{
Traumatic haemoperitoneum in a pony
}

\author{
Phebe de Heus', Denise Thaller², René van den Hoven' and Florien Jenner ${ }^{3}$ \\ ${ }^{1}$ Clinical Unit of Equine Internal Medicine, University Equine Hospital, Vetmeduni Vienna, AT \\ 2 Institute of Pathology and Forensic Veterinary Medicine, Vetmeduni Vienna, AT \\ ${ }^{3}$ Clinical Unit of Equine Surgery, University Equine Hospital, Vetmeduni Vienna, AT
}

\begin{abstract}
Summary: Horses suffering from haemoperitoneum typically present with colic symptoms and depression. Furthermore, anorexia and haemorrhagic shock indicated by pale mucous membranes, tachycardia and tachypnoea are frequently encountered. This report describes a case of traumatic haemoperitoneum in a 24 -year-old pony mare. The pony suffered from kick injuries by its pasture mate. Upon arrival at the hospital the pony was depressed and tachycardic, tachypnoeic with pale, sticky mucous membranes. Rectal and neurologic examinations were unremarkable. Laboratory work-up revealed a stress leukogram. Packed Cell Volume and Total Protein were within reference ranges. Ultrasonography of the thorax showed no abnormalities, but abdominal ultrasound suggested haemoperitoneum, which was confirmed through the yield of reddish fluid with a high packed cell volume $(45 \%)$ on abdominocentesis. Conservative treatment with crystalloid fluid and plasma fluid therapy was ineffective (no clinical improvement). Ongoing clinical signs indicating hypovolaemia strongly suggested active haemorrhage and a decision for exploratory surgery was made. Intraoperatively the source of bleeding could be identified as a ruptured liver vessel, but could not be visualised. The extent of damage to the liver was further assessed with intraoperative intra-abdominal ultrasound. By using ultrasound imaging we could evaluate the therapeutic options under consideration. Based on a guarded prognosis the owner elected euthanasia. Necropsy confirmed the intraoperative findings, but also revealed involvement of multiple other tissues including the diaphragm and pancreas. Intra-abdominal ultrasonography could aid intraoperative identification of the source of bleeding and the extent of injury in patients with haemoperitoneum in which anatomic restrictions and active bleeding impede direct visualisation.
\end{abstract}

Keywords: haemoperitoneum / haemoabdomen / liver / ultrasonography / laparotomy / traumatology

Citation: de Heus P., Thaller D., van den Hoven R., Jenner F. (2015) Traumatic haemoperitoneum in a pony. Pferdeheilkunde 31, $603-607$

Correspondence: Dr. Phebe de Heus, University for Veterinary Medicine, Vienna, Veterinärplatz 1, 1210 Vienna, Austria, E-mail: phebe.de-heus@vetmeduni.ac.at

\section{Introduction}

Horses suffering from haemoperitoneum typically present with colic symptoms and depression. Furthermore, anorexia and haemorrhagic shock indicated by pale mucous membranes, tachycardia and tachypnoea are frequently encountered (Conwell et al. 2010, Dechant et al. 2006). Abdominal distension is not a prominent feature of haemoperitoneum (Pusterla et al. 2005). Colic associated with haemoperitoneum is due to serosal irritation and/or the mechanical effect of a large volume in the abdomen (Goldberg 1961). Packed Cell Volume (PCV) and Total Protein (TP) are reported to be within or below the reference ranges (Conwell et al. 2010, Pusterla et al. 2005). Thrombocytopenia is found in the majority of horses with haemoperitoneum (Pusterla et al. 2005).

Intra-abdominal haemorrhage in horses may result from a variety of aetiological processes such as coagulopathies (Dechant et al. 2006), periparturient haemorrhage (Conwell et al. 2010, Mogg et al. 2006, Pusterla et al. 2005), bleeding from the gastrointestinal tract and its mesentery (Dechant et al. 2006) or rupture of predisposed vessels such as from a damaged iliac artery in case of pelvic fracture (Conwell et al. 2010, Dechant et al. 2006). Other reported causes of haemoperitoneum include rupture of the spleen, liver and/or kidney, as well as bleeding from various tumours (Alexander et al. 2004, Conwell et al. 2010, Dechant et al. 2006, Ferrucci et al. 2012, Mckay et al. 2003, Pusterla et al. 2005, Southwood et al. 2000). The spleen is the most frequently ruptured organ and also the most frequent cause of haemoperitoneum after trauma in horses (Dechant et al., 2006).
A history of trauma was reported in $9-25 \%$ of horses referred for evaluation of haemoperitoneum (Conwell et al. 2010, Dechant et al. 2006, Pusterla et al. 2005). Development of septic peritonitis may be a later complication (Mogg et al. 2006) because blood in the abdomen in principle is an excellent culture medium for bacterial growth.

Death due to haemoperitoneum is significantly associated with high respiratory rate (Dechant et al. 2006). Trauma and idiopathic aetiologies have a higher chance of survival compared to coagulopathies (Dechant et al. 2006).

Horses which develop haemoperitoneum after exploratory celiotomy for acute gastrointestinal disease represent a separate group. Clinical signs postoperative can be vague but were associated with haemoperitoneum for tachycardia, declining haematocrit and TP, abdominal discomfort and hemorrhagic incisional drainage (Gray et al. 2015). Gray et al. (2015) found that horses having a resection or anastomosis were at greater risk for haemoperitoneum than those undergone simple replacement and/or enterotomy. Survival to discharge for postoperative haemoperitoneum was $65 \%$. Peritonitis and adhesion formation were recognised as important sequela at necropsy for postoperative haemoperitoneum with a negative impact on prognosis (Gray et al. 2015). A specific set of differential diagnosis can be kept in mind for postoperative haemoperitoneum with systemic causes (coagulopathies) and inadvertent surgical trauma, but foremost amongst these remains ligation failure due to tissue failure or surgical error (Gray et al. 2015). 


\section{Case report}

History

A 24-year-old pony mare was referred to the University Equine Hospital of the Vetmeduni Vienna for evaluation of suspected internal injuries secondary to kick injury to the left abdomen and thorax by its pasture mate. The resulting skin lesions had been treated at home with aureomycin spray. The pony had also received unknown doses of caffeine and a homeopathic preparation $\left(\right.$ Traumee $^{\circledR}$ ) from the livery stable owner. The night after the accident the pony had shown no appetite, was depressed and developed pale mucosal membranes in combination with an unsteady gait. The local veterinarian was consulted the following morning and she referred the pony immediately.

\section{Clinical findings and diagnosis}

Upon arrival at the hospital the pony showed multiple superficial abrasions, consistent with trauma, mostly concentrated on the left side of thorax and abdomen. A swelling measuring $15 \times 10 \mathrm{~cm}$ was noted at the left flank. The pony was depressed and tachycardic (heart rate of 92 beats/minute). Her respiratory rate was elevated at 24 breaths/minute. Rectal temperature was $37.9^{\circ} \mathrm{C}$. The mucous membranes were pale and slightly tacky. The capillary refill time was $>3$ seconds, skin turgor was decreased and jugular filling time was delayed. Abdominal sounds were decreased in all quadrants. Results of a neurologic examination were unremarkable.

Examination per rectal palpation revealed no abnormalities. Transcutaneous ultrasonography of the thorax including the ribs was unremarkable. Abdominal ultrasonography showed swirling echogenic fluid and an inhomogeneous solid material bordering the ventral abdominal wall, suggesting a gravitated blood clot. The liver exhibited a normal edge and structure on the right side of the abdomen. The spleen was increased in size, extending far over the ventral midline. The mass at the left flank could be localised to the abdominal muscular layers and was presumed to be a haematoma.

Upon presentation total leucocyte count was within reference range $(8.7 \mathrm{G} / \mathrm{l}$, reference range $[\mathrm{rr}] 5.0-10.0 \mathrm{G} / \mathrm{l})$, but with mild lymphopenia $(0.76 \mathrm{G} / \mathrm{l}$, rr 1.0-4.5 G/l), and mild neutrophilia (7.7 G/l, rr 3.0-7.0 G/I), suggestive of a stress leukogram. PCV (32\%, rr 32-55\%; erythrocytes 6.8G/l, rr 6.5-11 G/I) and TP (72 g/l, rr 55-75 g/l) were within the reference ranges. Blood biochemistry revealed a creatinine concentration within reference range. Liver enzymes were not measured. Activated partial thromboplastin, prothrombin and thrombin times were all within the reference range. Thrombocyte count was decreased (77 G/I, rr 90-300 G/I). Ultrasound guided abdominocentesis yielded serosanguinous fluid with a PCV of $45 \%$, TP $40 \mathrm{~g} / \mathrm{l}(\mathrm{rr}<25 \mathrm{~g} / \mathrm{l})$ and specific gravity of 1.030 ( $r r<1.020)$, confirming the diagnosis of haemoperitoneum. However, the origin of the bleeding could not be determined.

\section{Treatment}

Conservative therapy was initiated, including crystalloid fluid therapy (3 Litres Ringer s Lactate ${ }^{2}$ as a small bolus and 10 Litres $0.9 \% \mathrm{NaCl}$ as a continuous rate infusion), gentamycin
$6.6 \mathrm{mg} / \mathrm{kg}$ bwt iv q $24 \mathrm{~h}\left(\right.$ Gentavan $\left.^{3}\right)$ and sodium-penicillin $14.000 \mathrm{lU}$ iv q $6 \mathrm{~h}$ (Penicillin-G-Natrium ${ }^{4}$ ), flunixin meglumin $1.1 \mathrm{mg} / \mathrm{kg}$ bwt iv q $12 \mathrm{~h}$ (Finadyne ${ }^{5}$ ) and cimetidine $^{2}$ $20 \mathrm{mg} / \mathrm{kg}$ bwt po q $8 \mathrm{~h}$. Cimetidine was given prophylactically to prevent equine gastric ulcer syndrome. Because of unknown vaccination history the pony received 7.500 IE tetanus antiserum sc (Equilis tetanus-serum ${ }^{5}$ ). Despite therapy the heart rate remained elevated, showing sinus tachycardia on the temporal electrocardiogram (ECG).

The pony displayed abdominal discomfort with turning the head toward the abdomen, bruxism, inappetence and lethargy. Thrombocyte count decreased to 61 G/l (rr 90-300 G/l) 24 hours post admission. The pony was treated with $2000 \mathrm{ml}$ plasma to provide exogenous coagulation factors. Repeated blood work also revealed a mild hypertriglyceridaemia (1.2 mmol/l, $\mathrm{rr}<0.57 \mathrm{mmol} / \mathrm{l})$. A repeated abdominocentesis yielded red fluid with a PCV of $52 \%$, elevated TP $(45 \mathrm{~g} / \mathrm{l}$, $\mathrm{rr}<25 \mathrm{~g} / \mathrm{l})$ and cell count $\left(10.1 \times 10^{9} \mathrm{cells} / \mathrm{I}\right)$, with macrophages $90 \%$, neutrophils $8 \%$ and eosinophils $2 \%$. The macrophages showed erythrophagocytosis and haemosiderophagocytosis. Active bleeding was suspected and the pony was referred to surgery for exploratory celiotomy ca. 48 hours after admission. Just before surgery PCV had dropped to $26 \%$ and TP was stable at $67 \mathrm{~g} / \mathrm{l}$. Cross-matching was performed to find a suitable blood donor in the teaching herd in preparation for an intended full blood transfusion intraoperatively.

\section{Surgical findings}

A ventral midline celiotomy was performed with the pony in dorsal recumbency. Upon opening the abdomen, haemoperitoneum was confirmed. Exploration of the abdomen revealed that the gastrosplenic ligament had torn over its entire length. While several large blood clots could be evacuated from this area and the mesenteric edges were bruised and still oozing small amounts of blood, no significant active bleeding was seen in this region. Active bleeding could be seen originating from the region of the liver. A defect extending through the liver capsule and an actively bleeding vessel in close proximity to the portal vein could be palpated near the border of the left and caudate lobe of the liver. However the source of haemorrhage could not be visualised due to the deep location in the abdomen and the continuous bleeding. Therefore, to determine the extent of liver injury, an intra-abdominal ultrasound of the liver was carried out intra-operatively with the probe covered in a sterile plastic arthroscopic camera drape. Active bleeding was confirmed from a superficial hepatic vessel (diameter ca. $5.4 \mathrm{~mm}$ ), using colour-flow Doppler ultrasound. Except for a hyperechoic rim around the ruptured vessel the liver displayed a normal sonographic architecture (Figure 1 and 2). In addition, diffuse haematomas and coagula along the dorsal mesentery were found. Based on the possible perioperative complications and the guarded prognosis the owner elected euthanasia for the pony.

\section{Post mortem}

At necropsy the intraoperative findings were confirmed. Clotted blood was seen on the visceral surface of the liver due to a tear (ca. $3 \mathrm{~cm}$ length) in a superficial intrahepatic branch of the portal vein (Pars transversa of the Ramus sinister), corresponding to the intraoperative findings (Figure 3). Histologic 
examination of this area revealed a focal granulocytic infiltration in conjunction with fibrin and focal haemorrhage most likely as a result of the trauma. Further mild interstitial fibrosis of the entire liver was found.

A massive subserosal and intramuscular haematoma occupying almost the entire diaphragm was present. Also multiple subcutaneous and subpleural haemorrhages mainly on the left side were found as well as multifocal bleeding in the

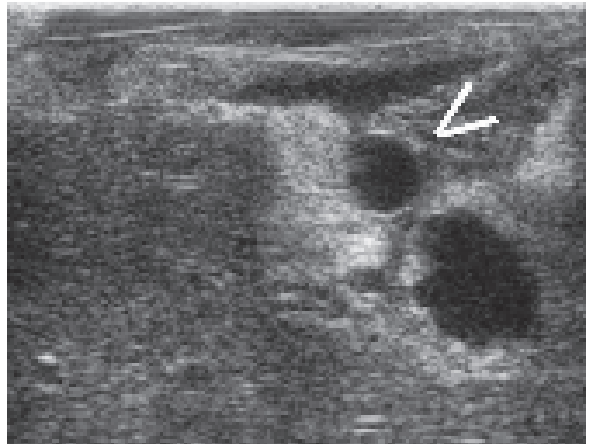

Fig. 1 Intraoperative ultrasound image $(10 \mathrm{MHz})$ of the liver showing the ruptured vessel (white arrowhead) with hyperechoic rim. Intraoperativer Ultraschall (10Mhz) der Leber zeigt das rupturierte Gefäß (weiße Pfeilspitze) mit einem hyperechogenen Rand.

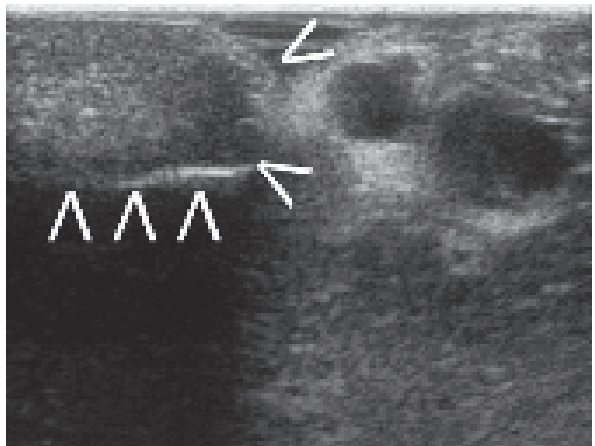

Fig. 2 Intraoperative ultrasound image $(10 \mathrm{MHz})$ of the liver showing the ruptured vessel (same as Figure 1) with the index finger of the surgeon (white arrowheads) confirming the ultrasound findings of outward flow by palpation.

Intraoperativer Ultraschall $(10 \mathrm{MHz})$ der Leber zeigt das rupturierte Gefäß (wie Abbildung 1) mit dem Zeigefinger der Chirurgin (weiße Pfeilspitzen) die den Ausfluss palpatorisch bestätigen.

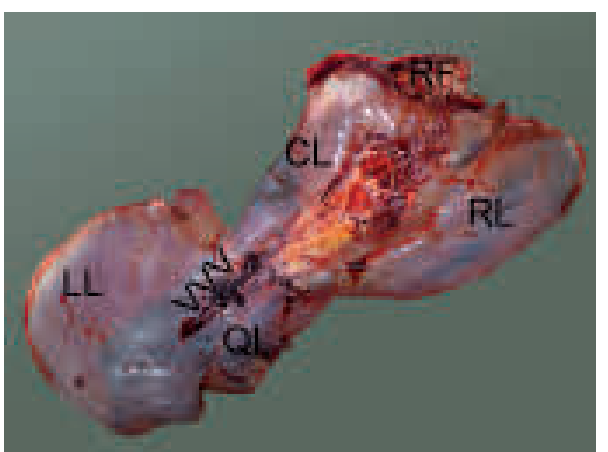

Fig. 3 Visceral surface of the liver. Black arrowheads point to the ruptured pars transversa of the ramus sinister. $\mathrm{RL}=$ right lobe, $\mathrm{LL}=$ leftlobe, $\mathrm{QL}=$ quadrate lobe, $\mathrm{CL}=$ caudate lobe and $\mathrm{RF}=$ renal fossa.

Viszerale Oberfläche der Leber. Die schwarze Pfeilspitze zeigt das rupturierte Gefäß (Pars transversa des Ramus sinister). RL = rechter Leberlappen, $L L=$ linker Leberlappen, $Q L=$ Lobus quadratus, $C L=$ Lobus caudatus und $R F=$ Nierenfossa. gastric serosa, near the pancreas and at the splenic hilus. The greater omentum was torn and showed clear coagula at its borders with the torn gastrosplenic ligament. The lungs were congested. Mild alveolar oedema and interstitial emphysema were noted. Both kidneys contained focal scar tissue consistent with mild infarct. The other organs were normal.

\section{Discussion}

During a ten-year period preceding the present case, seven cases of haemoperitoneum were additionally identified retrospectively in the records of the University Equine Hospital Vetmeduni Vienna. This population consisted of 2 mares and 5 geldings and represented one Haflinger, one Warmblood, one Irish cob, one Furioso, one Pinto and two Thoroughbreds between 4 and 23 years of age. Six cases were referred for colic symptoms and one for an abdominal wound. Four horses were euthanized and 3 were discharged. All four horses that were euthanized (on the owners request) arrived in severe hemorrhagic shock at the clinic and 3 collapsed upon offloading from the trailer or during the initial clinical examination. In 5 cases the source of bleeding could be identified intra-vitam and in 2 cases post-mortem. Three horses were diagnosed with splenic rupture and two with rib fractures (of which one had a suspected splenic haematoma on ultrasound and the other had unknown damage to the internal organs). One horse was diagnosed with a ruptured ovarian haematoma and one with abdominal haemorrhage secondary to $T$ cell lymphoma with necrosis of the colon wall and its vessels. The lymphoma was already diagnosed on complaints of weight loss through the yield of tumor cells in a smear of fluid obtained by abdomincentesis 21 days before the horse was presented with haemoperitoneum.

In the presented case of the pony the diagnosis of haemoperitoneum was straightforward. The poor response to conservative treatment including sinus tachycardia indicated ongoing haemorrhage and hypovolaemia leading to the decision for surgical exploratory celiotomy. Ventricular tachycardia and increased troponin I were reported in a foal with haemoperitoneum and haemorrhagic shock (Muurlink et al. 2008). How-ever our case was not continuously monitored with ECG, possibly overlooking arrhythmias. The diaphragmatic haematoma as seen in our case could have contributed to altered diaphragmatic movement and a more thoracic breathing pattern. The initial crystalloid fluid therapy strategy was chosen as conservative resuscitation to restore circulating volume without raising blood pressure dramatically and disrupting the potential blood clot. Later, plasma was used to promote haemostasis.

Our case suffered from multi-organ trauma, with the gastrosplenic ligament, the liver and the pancreas most severely affected. The final diagnosis was largely made during an exploratory celiotomy and confirmed post-mortem. Alternatively, laparoscopy could have been performed. Laparoscopy has been described to diagnose spleen and dorsal mesentery haematoma in the horse (Mehl et al. 1998, Sutter and Hardy 2004). In this case exploratory celiotomy was chosen because celiotomy offered potentially better therapeutic options. According to the (human) American Association for the Surgery of Trauma Liver Organ Injury Scale (1994 revision), the liver 
injury in this case can be classified as Grade V (vascular damage injury involving central major hepatic vein). Had the owner decided to continue treatment, ligation of the ruptured vessel in the liver or liver lobe resection could have been attempted. However, haemorrhage from multiple other locations such as the mesenteric root, the torn omentum and the bruised appearance of the stomach complicated treatment and decreased the prognosis significantly. In addition the close proximity of the aorta, vena cava and the portal vein would have made the blind ligation of the torn hepatic vessel technically challenging. Ligation of an intrahepatic branch of the portal vein could interrupt circulation in a large part of the liver with subsequent post-operative complications (i.e. liver necrosis).

In humans the liver is one of the commonly injured organs subsequent to blunt abdominal trauma (Hommes et al. 2013). The anatomy of the human liver however is different, with a more superficial location. In the adult horse the entire liver is contained in the rib cage and only a small portion directly borders the abdominal wall where it is accessible for ultrasonography. In human medicine there is a tendency toward medical treatment in cardiovascularly stable patients in cases of haemoperitoneum. Computer Tomography is the major diagnostic tool in human medicine to localise haemorrhage in haemoperitoneum or liver injury, which is not possible in adult horses (size restrictions due to a limited gantry bore diameter). Blunt impact model and simulation studies from human livers showed that different lesions develop with different impact angles. The general theory of liver injury mechanism also suggests that the liver may be injured by motion relative to the rest of the body during rapid deceleration (Shao et al. 2013).

Intraabdominal ultrasonography could aid intraoperative identification of the source of bleeding and the extent of injury in patients with haemoperitoneum in which anatomic restrictions and active bleeding impede direct visualisation.

\section{Acknowledgements}

We would like to thank the referring veterinarian for sending this pony to the University Equine Hospital of the Vetmeduni Vienna and Klaus Bittermann for excellent photographic work.

\section{Manufacturer's addresses}

1 Dr Peithner KG nunmehr GmbH \& Co, Wien, Austria

2 Apotheke LKH, Wien, Austria

3 Vana Wien, Austria

${ }^{4}$ Sandoz Pharma GmbH, Barleben, Germany

5 MSD Animal Health GmbH Wien, Austria

\section{References}

Alexander G. R., Tweedie M. A., Lescun T. B., McKinnon A. O. (2004) Haemoperitoneum secondary to granulosa cell tumour in two mares. Austr. Vet. J. 82, 481-484

Conwell R. C., Hillyer M. H., Mair T. S., Pirie R. S., Clegg P. D. (2010) Haemoperitoneum in horses: a retrospective review of 54 cases. Vet. Rec. 167, 514-518

Dechant J. E., Nieto J. E., Le Jeune S. S. (2006) Hemoperitoneum in horses: 67 cases (1989-2004). J. Am. Vet. Med. Assoc. 229, 253-258
Ferrucci F., Vischi A., Zucca E., Stancari G., Boccardo A., Rondena M., Riccaboni P., Ferro E. (2012) Multicentric Hemangiosarcoma in the Horse: A Case Report. J. Equine Vet. Sci. 32, 65-71

Goldberg H. M. (1961) A physical sign of haemoperitoneum. Lancet 277, 1352-1353.

Gray S. N., Dechant J. E., Acvs D., Lejeune S. S., Acvs D., Nieto J. E., Acvs D. (2015) Identification, Management and Outcome of Postoperative Hemoperitoneum in 23 Horses After Emergency Exploratory Celiotomy for Gastrointestinal Disease. Vet. Surg. 44, 379-385

Hommes M., Kazemier G., Schep N. W. L., Kuipers E. J., Schipper I. $B$. (2013) Management of biliary complications following damage control surgery for liver trauma. Eur. J. Trauma Emerg. Surg. 39, $511-516$

Mckay J. S., Clegg P. D., Morthole V. I., Blake C. L. (2003) Case Reports Primary retroperitoneal tumour in a horse. Equine Vet. J. 35, 103-106

Mehl M. L., Ragle C. A., Mealey R. H., Whooten T. L. (1998) Laparoscopic diagnosis of subcapsular splenic hematoma in a horse. J. Am. Vet. Med. Assoc. 213, 1171-1173

Mogg T. D., Hart J., Wearn J. (2006) Postpartum hemoperitoneum and septic peritonitis in a Thoroughbred mare. Vet. Clin. Equine Pract. 22, 61-71

Muurlink M. A., Walmsley J. P., Savage C. J., Whitton R. C. (2008) Splenectomy in a foal to control intra-abdominal haemorrhage caused by splenic rupture. Equine Vet. Educ. 20, 362-366

Pusterla N., Fecteau M. E., Madigan J. E., Wilson W. D., Magdesian K. G. (2005) Acute hemoperitoneum in horses: a review of 19 cases (1992-2003). J. Vet. Intern. Med. 19, 344-347

Shao Y., Zou D., Li Z., Wan L., Qin Z., Liv N., Zhang J., Zhong L., Huang P., Chen Y. (2013) Blunt liver injury with intact ribs under impacts on the abdomen: a biomechanical investigation. PloS one 8, e52366. doi:10.1371/journal.pone.0052366

Southwood L. L., Schott H. C., Henry C. J., Kennedy F. A., Hines M. T., Geor R. J., Hassel D. M. (2000) Disseminated hemangiosarcoma in the horse: 35 cases. J. Vet. Intern. Med. 14, 105-109

Sutter W. W., Hardy J. (2004) Laparoscopic Repair of a Small Intestinal Mesenteric Rent in a Broodmare. Vet. Surg. 33, 92-95

Erweiterte Zusammenfassung

Traumatisch bedingtes Hämoperitoneum bei einem Pony

Pferde mit Hämoperitoneum prösentieren sich typischer weise mit Koliksymptomen und vermindertem Allgemeinbefinden. Außerdem wurden Anorexie und Symptome eines hämorrhagischen Schocks, wie anämische Schleimhäute, Tachykardie und Tachypnoe beschrieben. Ein vermehrter Umfang des Abdomens ist kein typisches Leitsymptom. Labordiagnostisch sind der Hämatokrit und das Totalprotein erniedrigt oder sogar im Normbereich. In den meisten Fällen wird auch eine Thrombozyłopenie gefunden. Die Ätiologie des Hämoperitoneums ist mannigfaltig und reicht von Koagulopathien, peripartalen Blutungen und Blutungen des Gastrointestinaltrakts, der Gekrösewurzel und prädisponierter Gefäßstrukturen wie zum Beispiel die Arteria lliaca bei Beckenfrakturen. Weitere Ursachen stellen Blutungen aus abdominalen Organen wie Milz, Leber oder Nieren und Tumoren dar. Die Milz ist das am häufigsten betroffene Organ vor allem bei Trauma Patienten. Traumatische und idiopathische Ätiologien haben eine bessere Prognose im Vergleich zur Koagulopathien.

Sieben Pferde (vorliegender Fall ausschließend) wurden mit Hämoperitoneum im Zeitraum zwischen 2003 und 2013 an die Universitätsklinik für Pferde der Veterinärmedizinischen 
Universität Wien vorgestellt. Die Ursache der Blutung konnte bei 5 Pferden intra-vitam und bei 2 Pferden post-mortem identifiziert werden. Drei Pferde hatten eine Milzruptur, 2 Pferde Rippenfrakturen (wovon 1 Pferd zusätzlich eine Milzruptur hatte), 1 Pferd hatte ein rupturiertes Ovarhämatom und ein Pferd blutete aus einem die Kolongefäße infiltrierenden Lymphom. Drei Pferde wurden nach Hause entlassen und 4 Pferde wurden euthanasiert.

Eine 24-järige Ponystute wurde als Notfall mit dem Verdacht auf innere Blutungen als Folge von Schlagverletzungen an die Universitätsklinik für Pferde der Veterinärmedizinischen Universität Wien überwiesen. Das Pony zeigte mehrere oberflächliche Abschürfwunden vor allem auf der linken Körperseite. Das Pony war lethargisch, und sowohl die Herzfrequenz (92 Herzschläge/min) als auch die Atemfrequenz (24 Atemzüge /min) waren erhöht. Die innere Körpertemperatur lag bei $37.9^{\circ} \mathrm{C}$. Die Schleimhäute waren anämisch und verwaschen. Die kapilläre Rückfüllungszeit war mit drei Sekunden verlängert und das Blutangebot mittelgradig verzögert. Die Darmperistaltik war beidseits vermindert. Die neurologische und rektale Untersuchung zeigte keinen besonderen Befund. Eine ultrasonographische Untersuchung des Thorax inklusive den Rippen lieferte keinen auffälligen Befund. Im transkutanen abdominalen Ultraschall stellte sich hochgradig vermehrt verwirbelnde echogene Flüssigkeit dar mit einer gekammerten inhomogenen Struktur am tiefsten Punkt des Abdomens, die an ein Blutgerinnsel denken ließ. Die Leber auf der rechten Seite des Abdomens war sonographisch unauffällig. Die Milz erschien vergrößert und war ultrasonographisch noch weit rechts der linea alba sichtbar.

Die hämatologische Untersuchung ergab eine milde Lymphopenie und milde Neutrophilie, die Gesamtleukozytenzahl lag im Normbereich, was auf ein Stressleukogramm hindeutet. Hämatokrit, Totalproteingehalt und Kreatiningehalt lagen im Normbereich, Leberenzyme wurden nicht gemessen. Die Gerinnungszeiten waren im Normbereich aber die Thrombozyłenzahl war erniedrigt. Die gewonnene Abdominalflüssigkeit war rötlich verfärbt mit einem Hämatokrit von 45\%, Totalproteingehalt $40 \mathrm{~g} / \mathrm{l}(\mathrm{Rl}:<25 \mathrm{~g} / \mathrm{l})$ und einem spezifischem Gewicht von 1.030 (RI: <1.020), wodurch die Diagnose Hämoperitoneums bestätigt wurde. Eine Zellzählung der Abdominalflüssigkeit wurde nicht durchgeführt. Die Ursache der Blutung konnte mittels ultrasonographischer und klinischer Untersuchungen nicht identifiziert werden.

Die Therapie umfasste Infusionen mit kristalloiden Flüssigkeiten und Plasma, Breitbandantibiotika, nicht-steroidale Antiphlogistika (NSAID), Tetanus Antiserum, und Cimetidin (Equine Gastric Ulcer Syndrome Prophylaxe). Da die hämodynamische Entgleisung angesichts der Therapie anhielt, wurden anhaltende Hypovolämie und Hämorrhagie vermutet und eine Laparotomie empfohlen um die Quelle der Blutung zu suchen und wenn möglich zu beheben. Kreuzproben wurden durchgeführt um einen kompatiblen Blutdonor für eine Vollbluttransfusion in der Universitätsherde zu finden.

Die Laparotomie wurde unter Vollnarkose in Rückenlage durch eine ventrale Mittellinieninzision durchgeführt. Das Hämoperitoneum wurde bestätigt sobald das Abdomen geöffnet wurde. Bei der Exploration des Abdomens wurde festgestellt, dass das Ligamentum gastrolienale über seiner gesamten Länge zerrissen war. Obwohl dort mehrere Blutkoagula gefunden wurden, wurden zum Zeitpunkt der Operation nur eine minimale Sickerblutung und keine signifikante Blutung in dieser Region beobachtet. Eine aktive Blutung konnte allerdings im kranialen Teil des Abdomens vorgefunden werden: in der Nähe der Vena portae war ein Leberkapselriss mit signifikantem Blutausfluss palpatorisch nachweisbar. Aufgrund der tiefen Lokalisation im Abdomen, des kontinuierliches Blutens und der Nähe zur Vena portae, konnte das volle Ausmaß und die Zugänglichkeit für die Ligatur des vermuteten blutenden Astes der Vena portae nicht festgestellt werden. Zusätzlich wurden noch Hämatome und Koagula entlang der dorsalen Gekrösewurzel gefunden. Daher wurde ein intra-operativer intra-abdominaler Ultraschall durchgeführt um die Diagnose zu spezifizieren, das Ausmaß des Lebertraumas fest zu stellen und therapeutische Optionen auszuloten. Aufgrund der vorsichtigen Prognose, und da doch mehrere Organe und Blutungsstellen betroffen waren und die Besitzerin, aufgeklärt über mögliche perioperative Komplikationen, lehnte weitere Therapien ab, daher wurde das Pony noch am Tisch euthanasiert.

Die pathologische Untersuchung des Ponys ergab multiple subkutane und subpleurale Blutungen an der linken Flanke und Brustwand. Das Zwerchfell wies ausgedehnte subseröse und intramuskuläre Blutungen auf, brustkorbseitig in stärkerem Ausmaß als Bauch-seitig. Ein ca. $3 \mathrm{~cm}$ langer Gefäßriss eines oberflächlichen Astes der Portalvene (Pars transversa des Ramus sinister), wurde übereinstimmend mit dem chirurgischen Befund festgestellt. Multifokale Blutungen waren sichtbar in der Serosa des Magens, in der Nähe des Pankreas und im Bereich des Milzhilus. Beide Nieren zeigten Infarktnarben in mäßiger Anzahl. Zu den weiteren Befunden zählten deutliche Stauung der Lunge, ein geringgradiges alveoläres Ödem sowie interstitielles Emphysem. Die übrigen Organe waren ohne Besonderheiten. Bei der pathohistologischen Untersuchung der Leber wies das Gewebe an der Rupturstelle eine granulozytäre Infiltration sowie Fibrinaustritt und eine fokale Blutung auf. Das übrige Lebergewebe erschien bis auf eine geringgradige Fibrosierung des Interstitiums unauffällig.

Im den vorliegenden Fall wurde eine Laparotomie anstelle einer Laparoskopie gewählt da man sich mit dieser Methode bessere therapeutische Optionen erhoffte, obwohl die Laparoskopie als gute Methode zur Diagnose von Hämatomen der Milz und der dorsalen Gekrösewurzel beschrieben wird. Mögliche Therapie-Optionen für dieses Pony wären die Ligatur des gerissenen Gefäßes oder die Resektion des Leberlappens gewesen. Aufgrund der Tiefe des gerissenen Gefäßes hätte die Ligatur blind durchgeführt werden müssen, was durch die Nähe zur Aorta, Vena cava und Portalvene, ein großes Komplikationspotential hat. Eine weitere mögliche Komplikation der Ligatur wäre eine Lebernekrose aufgrund sekundärer Zirkulationslimitationen eines potentiell großen Teiles der Leber gewesen.Der intraabdominale Ultraschall kann während einer Operation helfen, die exakte Blutungsursache eines Hämoperitoneums zu identifizieren und den Umfang der Pathologie fest zu stellen, wenn durch Blutungen und anatomische Restriktionen eine direkte Visualisierung nicht möglich ist.

Schlüsselwörter: Hämoperitoneum / Hämoabdomen / Leber / Ultraschall / Laparotomie 